be readily seen by comparing the thoroughly Aryan structure of the few sentences of old Graulish extant.

Those are the races which have been inferred in the course of these remarks, in which I have proceeded on the principle that each successive band of conquerors has its race, language and institutions eventually more or less modified by contact with the race, language and institutions of those whom it has conquered. That looks simple enough when stated so, but the result which we get proves complicate. In any case I have endeavoured in this address to substitute for the rabble of divinities and demons, of fairies and phantoms that disport themselves at large in Celtic legend, a possible series of peoples, to each of which should be ascribed its own proper attributes. But that will only be possible if we can enlist the kindly aid of the Muse of Archæology.

\section{THE INTERNATIONAL CONGRESS OF APPLIED CHEMISTRY.}

THIS congress was held in Paris during the last week of July, M. Moissan being president and M. Berthelot honorary president. The work was divided into ten sections : analytical chemistry, chemical industry of inorganic products, metallurgy, mines and explosives, chemical industry of organic products, the sugar industry, chemical industry of fermentation, agricultural chemistry, hygiene, food analysis, medical and pharmaceutical chemistry, photography, and electrochemistry. More than two hundred papers were read and discussed, and numerous resolutions were passed, of which the following were the most important. In view of the great inconvenience caused commercially by uncertainty in the atomic weights used by analytical chemists, the congress, hoping that the adoption of the atomic weight of oxygen as a base $(O=16)$ would lead to a greater certainty and to a simplification in the calculation of atomic weights, agreed to work in unison with the International Commission on atomic weights. It further suggested the necessity for an International Commission for fixing methods and coefficients of analysis in commercial work. Committees were also appointed to deal with questions of indicators in volumetric work, analysis of manures, potash estimation, and the use of sulphurous acid in wine. In the second section the chief questions dealt with were the determination of high temperatures, construction of glass and porcelain furnaces, the manufacture of sulphuric acid, and of barium and hydrogen peroxides. In the section of metallurgy, mines and explosives, papers were read dealing with the sampling of minerals, the constitution of iron and steel, the use of the microscope in the study of metals, utilisation of waste heat, and the estimation of sulphur, manganese and phosphorus in metals. In the section dealing with the industry of organic substances the most important discussion was on the use of alcohol for other than drinking purposes, and a series of resolutions was passed stating that in the opinion of the congress no duty should be charged upon alcohol used in the preparation of pharmaceutical and chemical products. In the case of alcohol intended for use as fuel, the sub stances added should be of a character appropriate to its use, not too costly, and not containing any non-volatile substance. Any attempt to recover pure alcohol from methylated spirit should be liable to severe penalties, and all makers of stills should be compelled to give particulars to the excise authorities of stills sold or repaired. In the other sections discussions were held on the relation of the sugar industry to the State, the methods of analysis of wines and spirits, the carbide industry, manufacture of percarbonates, and numerous other papers of interest.

\section{UNIVERSITY AND EDUCATIONAL} INTELLIGENCE.

IT is officially announced that Mr. L. R. Wilberforce, demonstrator in physics at the Cavendish Laboratory, Cambridge, and University lecturer in physics, has been appointed to the Lyon Jones chair of experimental physics at University College, Liverpool, vacated by the removal of Dr. Oliver Lodge to the University of Birmingham.

The Admiralty has created an important new post in the Dockyard staff, namely, that of electrical engineer, to rank next to the four chief assistant engineers. To fill this post the Admiralty has chosen Mr. Louis J. Steele, M.I.E.E., late chief engineer of Messrs. Verity, and formerly assistant engineer with Messrs. Johnson and Phillips. Mr. Steele received his NO. I6i2, VOL. 62] training at the Technical College, Finsbury, under Prof. Silvanus Thompson and Prof. Perry, and carried off the certifcate of the College in 1890 . He will be attached to the Dockyard staff at Portsmouth.

InstRUCtion in chemistry is well provided for at the Goldsmiths' Institute, New Cross. During the session about to commence, Mr. W. J. Pope will give courses of lectures on oils, fats and waxes, organic chemistry with special reference to recent work and current views, inorganic chemistry and stereochemistry. In this last course of lectures, the principles which form the foundation of stereochemistry will be discussed, together with the methods which have led to the discovery of stereoisomerism amongst compounds of carbon, nitrogen, tin and sulphur. Particular attention will be paid to the bearing of stereochemistry upon current chemical problems. Lectures in chemistry will also be given by Mr. Stanley J. Peachey.

DURING the past year the Degree of Doctor of Philosophy was conferred by twenty-two Universities in the United States upon 233 candidates. The distribution of these degrees among the various Universities, and the subjects taken, are dealt with in an article in Science. It appears that 120 of the degrees were granted to students of the humanities, and II 3 for scientific subjects. The tables show that the humanities are favoured at Havard and Yale Universities, and the sciences at Johns Hopkins, Columbia and Cornell Universities. Last year Johns Hopkins gave more than its proportionate share of degrees in chemistry, physics, zoology and physiology, Chicago in mathematics, geology, sociology and education, Harvard in physics, zoology and anthropology, Columbia in astronomy, botany, zoology and education, Yale in palæontology and psychology, Cornell in botany and psychology, and Clark in mathematics, psychology and education. The six science subjects in which most students presented theses are as follows:-Chemistry 26 , physics I5, botany 12, mathematics Ir, zoology II, psychology 9.

EVER since the funds were provided for technical education in this country, it has been insisted upon in these columns, and by men of science generally, that such education could only be profitably carried on by giving rational instruction in scientific principles instead of attempting to teach actual processes and trade methods, which are constantly in a state of flux on account of new developments. The most gratifying characteristic or educated opinion at the present time is the acceptance of this view; and it is especially noteworthy in connection with the substitution of nature study for agriculture in rural schools. In an address recently delivered before the Cheshire College or Agriculture, Prof. Robert Wallace dwelt upon the relation between the work of an agricultural school and actual farm work, and showed himself in complete sympathy with the view which has been expressed over and over again in these columns. Here is the case in a few words:- "What a young farmer should learn is not ordinary farm work, viz. to plough and harrow a given area in the day. He can become an expert at that kind of thing at home to greatest advantage, without cost for instruction, and at the same time prove a valuable aid to his father. He requires to be taught just those things which are not to be learned on an ordinary farm, to have explained to him the meaning of processes which are founded on scientific principles, and to become familiar with the common facts of those sciences which bear upon agricultural practice." If this had been borne in mind by Technical Instruction Committees in rural districts from the time they came into existence, their efforts would have received more encouragement from practical men, and have been attended with better results, than have been attained in many cases.

\section{SCIENTIFIC SERIALS.}

Transactions of the American Mathematical Society, vol. i. No. 3.-Wave propagation over non-uniform electrical conductors, by M. I. Pupin, is a paper read before the society in December last. The main object of it is the solution of a problem which, looked at from a purely mathematical point os view, can be stated as follows :-Find the integral of the partial differential equation $\mathrm{L} \frac{d^{2} y}{d t^{2}}+\mathrm{R} \frac{d y}{d t}=\frac{1}{\mathrm{C}} \frac{\delta^{2} y}{\delta s^{-}}$, and determine it so as to satisfy $k+2$ boundary conditions, where $k+1$ is the number of coils. The principal difficulty is to determine 
the proper mathematical formulation of these sundry conditions so as to obtain a system of equations which can be readily solved. The paper is illustrated by diagrams which put the problems discussed in a clear light. - "Ueber systeme von differentialgleichungen dessen vierfach periodische functionen genuige leisten," by M. Krause, was presented at the Chicago (April) meeting of the present year. References are given to Hermite ("Sur quelques applications de la théorie des fonctions elliptiques," I 885 ), and to a paper by Picard (Comples rendus, Band 89), and to previous work by the author-E. B. van Vleck follows with a paper on linear criteria for the determination of the radius of convergence of a power series. Its object is to establish criteria for the convergence of a power series when the $(n+1)$ th coefficient $A_{n}$ is connected with the preceding coefficients by a linear relation which tends to take a limiting form as $n$ increases indefinitely. The criteria include Cauchy's ratiotest as a special case, and may be looked upon as an extension of the test, and are applicable in cases in which the simple ratiotest fails. The paper closes with two theorems which are an extension for the case of two variables, criteria for the convergence of power series in such a case are stated to be very rare.-On the existence of the Green's function for the most general simply connected plane region, by W.F. Osgood.-A short but suggestive note- "D" lines on quadrics, by A. Pell. These lines, so named by Cosserat, were originally considered by Darboux. They are the lines drawn upon a surface in such a way that the osculating sphere at every point is tangent to the surface at that point. In addition to the above, the lines have been studied by Enneper and Ribaucour (for surfaces in generai). In the present paper the author applies the theory ol elliptic functions to the integration of Darboux's differential equation, and obtains an idea of the appearance of the lines and also some of their properties. - Starting from an article, by Prof. F. Morley, in the previous number of the Transactions, F. H. Loud gives sundry metric theorems concerning $n$ lines in a plane. By giving a different interpretation to formulze got by Prof. Morley, Mr. Loud obtains a new series of theorems and other results of some interest. - An application of group theory to hydrodynamics, by E. J. Wilczynski. It was observed by Sophus Lie that the stationary motion of a fluid can serve as a perfect picture of a one-parameter group in three variables. Apparently this fact has not been utilised for the purposes of hydrodynamics. This paper does this. Amongst other advantages, the treatment, from the new standpoint, leads to special cases of exceptional interest and importance, which otherwise appear to be difficult and unpromising.-Dr. L E. Dickson, following up work recently published in the Proceedings of the London Mathematical Society (vol. xxxi. pp. 30, 35I), contributes an article on the determination of an abstract simple group of order $2^{7} \cdot 3^{6 \cdot 5} \cdot 7$, holohedricaily isomorphic with a certain orthogonal group and with a certain hyperabelian group (contributed to the Chicago [April] meeting of the society).

In the Journal of the Royal Microscopical Society for August, Mr. E. M. Nelson has one of his useful technical articles on the "lag" in microscopic vision, as well as a historical account of the improvements in the structure of the microscope introduced by the firm of Ross. Mr. E. B. Stringer describes a new form of fine adjustment. Miss A. Lorrain Sinith gives a description of some new microscopic fungi, including a new species of Entomophthora, not parasitic, but saprophytic on dead animal tissues. There is, in addition, the usual summary of current researches relating to zoology, botany and microscopy.

In the Journal of Botany for August, Messrs. W. and G. S. West have a second instalment of their notes on freshwater algæ, in which some new species and varieties are described. The remaining papers are descriptive or geographical.

\section{SOCIETIES AND ACADEMIES. \\ PARIS.}

Academy of Sciences, September IO.-M. Maurice Lévy in the chair.-Occultation of Saturn by the moon on September 3 observed at the Observatory of Lyons, by MM. J. Guillaume, G. Le Cadet and M. Luizet.-On differential systems with a general uniform integral, by M. Paul Painlevé. Four types of systems are examined, problems in mechanics such as the movement of a heavy body fixed by a point, the inversion of total differentials, the case where the general integral of a differential system does not admit of transcendental singularities, and the

No. I6I2, voL. 62 ] study of the integrals of a differential system in a real field.-On the liquefaction of air by expansion with production of external work, by M. Georges Claude.-On the dielectric cohesion of gases and vapours, by M. E. Bouty. The experiments previously described upon the relation existing between the distance at which insulation breaks down and the pressure of the gas have been extended to vapours of liquids. Results of measurements for water, and eleven organic liquids, are given in the present paper. -.-On the modification of the electrical and organic properties of cables under the prolonged action of currents, by M. Georges Rheins. When a cable is submitted to the action of an alter. nating current it preserves its electrical and organic properties intact. With a continuous current in one direction the cable gradually loses its electrical properties, this effect being produced by the slow penetration of the copper from the wire into the sheath. The effect is similar with both gutta and paper coatings. - New researches on the absorptive power of hæmoglobin for oxygen and carbonic acid, by M. L. G. de SaintMartin. As the result of numerous experiments quoted, the author is of opinion that, contrary to the views generally held, it is impossible, especially in pathological cases, to estimate hremoglobin by means of the absorbing power of the blood.-On the nitrocelluloses, by M. Léo Vignon. Both the nitrocelluloses and the nitro-oxycelluloses energetically reduce Fehling's solution, their reducing power being apparently independent of the degree of nitration. The reducing powers of the nitration products of cellulose and oxycellulose are of the same order, about one-fifth that of inverted sugar.-On the wood of the Conifers of peat bogs, by M. L. Géneau de Lamarlière. In the wood of Conifers taken from a peat bog, the intercellular layer formed of lignin and pectic compounds is intact, whilst the internal portion has been strongly attacked by microbial action. The lignin and cellulose have disappeared, an amorphous substance remaining behind which is soluble in potash after the action of chlorine. The material resembles callose.Infiuence of a dry or moist medium upon the structure of planis, by M. Eberhardt. Compared with normal air, the effect of dry air is to increase the thickness of the epidermal cuticle and the number of stomata, to make the cork layer form earlier, to increase the production of ligneous tissue, and to cause an increase in the amount of pallisade tissue in the leaf.

\section{CONTENTS.}

A Magnetic Theory of the Universe. By Prof. R.

Meldola, F.R.S. . . . . . . . . 493

Our Book Shelf :-

Horovitz: "Untersuchungen über Philons und Platons Lehre von der Weltschöpfung."-H. W. B.

McAlpine: "Fungus Diseases of Citrus Trees in Australia, and their Treatment"

"Missouri Botanical Garden. Eleventh" Annual Report"

Letters to the Editor:-

Atmospheric Electricity and Dew-ponds.-Arthur Marshall

Huxley and his Work.-C. Simmonds A Large

Large Puff Balls.-W. A. Sanford . . . . . .

"A Tour through Great Britain in i $727 . "-S$. L. Petty

Prof. Henry Sidgwick

Prof. James Edward Keeler

Our Astronomical Column:- . . . . . . . 497

Ephemeris for Observations of Eros . . . . . 501

Swift's Comet (I892 I.) . . . . . . . 501

Th $=$ Bradford Meeting of the British Association :Section D. - Zoology.-Opening Address by Dr. Ramsay H. Traquair, F.R.S.

Section F.-Economic Science and Statistics.Opening Address by Major P. G. Craigie, President of the Section .........

Section H.-Anthropology.-Opening Address by Prof. John Rhys, President of the Section . .

The International Congress of Applied Chemistry 519 University and Educational Inteiligence . . . 519 Scientific Serials ........... . 519 Societies and Academies ....... 520 